\title{
MENINGKATKAN KESIAPAN DAN HASIL BELAJAR SISWA PADA PEMBELAJARAN KIMIA DENGAN PEMBERIAN KUIS DI AWAL PEMBELAJARAN
}

\author{
Made Gautama Jayadiningrat ${ }^{1},{ }^{*}$, I Nyoman Tika², Ni Putu Yuliani ${ }^{3}$ \\ 1 Universitas Pendidikan Ganesha \\ 2Universitas Pendidikan Ganesha \\ ${ }^{3}$ SMA Negeri 2 Singaraja
}

\begin{abstract}
Abstrak
Penelitian ini bertujuan untuk meningkatkan hasil belajar kimia siswa kelas XII MIA 4 SMA Negeri 2 Singaraja melalui pemberian kuis di awal pembelajaran. Jenis penelitian ini tergolong penelitian tindakan kelas (PTK) yang dilakukan dalam dua siklus. Setiap siklus terdiri dari tahap perencanaan, pelaksanaan tindakan, evaluasi, dan refleksi. Subjek penelitian ini adalah siswa kelas XII MIA 4 SMA Negeri 2 Singaraja tahun ajaran 2016/2017 yang berjumlah 36 orang, terdiri dari 15 orang laki-laki dan 21 orang perempuan. Data kesiapan belajar siswa dikumpulkan melalui test kuis di awal pembelajaran dan data hasil belajar siswa dikumpulkan melalui tes hasil belajar berbentuk uraian yang dilaksanakan setiap akhir siklus. Data-data yang telah dikumpulkan dianalisis secara deskriptif. Hasil penelitian menunjukkan bahwa pemberian kuis sebelum proses pembelajaran dapat meningkatkan kesiapan belajar siswa kelas XII MIA 4 SMA Negeri 2 Singaraja Tahun Ajaran 2016/2017. Berdasarkan hasil penelitian, diperoleh bahwa peningkatan persentase ketuntasan siswa dalam mengerjakan soal kuis dari siklus I ke siklus II yaitu sebesar 58,3\%. Selain itu, berdasarkan hasil pengerjaan tes hasil belajar diperoleh peningkatan persentase ketuntasan siswa sebesar $58,33 \%$.
\end{abstract}

Kata-kata kunci:

Kuis, hasil belajar

kimia

\section{Pendahuluan}

Perkembangan jaman yang semakin modern terutama pada era globalisasi seperti sekarang ini menuntut adanya sumber daya manusia yang berkualitas tinggi. Peningkatan kualitas sumber daya manusia merupakan prasyarat mutlak untuk mencapai tujuan pembangunan dan kemajuan suatu bangsa. Salah satu wahana untuk meningkatkan kualitas sumber daya manusia tersebut adalah melalui bidang pendidikan. Dengan demikian, inovasiinovasi dalam bidang pendidikan sangat diperlukan agar kualitas pendidikan terus meningkat sehingga dapat dihasilkan sumber daya manusia dengan kualitas tinggi dan tujuan pembangunan pun tercapai.

Peningkatan kualitas pendidikan terus diupayakan oleh masyarakat dan pemerintah. Berbagai upaya telah dilakukan oleh pemerintah dalam mewujudkan peningkatkan mutu pendidikan di Indonesia. Upaya-upaya tersebut diantaranya dengan melakukan pengadaan sarana dan prasarana pendidikan, seperti laboratorium di masing-masing sekolah, perpustakaan, perbaikan gedung sekolah, pelatihan guru-guru, sertifikasi guru dan dosen, inovasi pembaharuan metode pembelajaran, serta penyempurnaan kurikulum.

Mata pelajaran kimia termasuk mata pelajaran sains yang memiliki peran sangat penting dalam kehidupan. Peran kimia dapat dilihat dari berbagai sektor kehidupan seperti dalam bidang kesehatan, pertanian, industri, geologi, ekonomi, hukum, dan perkembangan ilmu pengetahuan dan teknologi. Hal ini berkaitan dengan hakikat ilmu kimia itu sendiri yang mempelajarai tentang komposisi, susunan, struktur dan sifat, perubahan, dinamika, dan energetika (Sunarya, 2010). Dengan demikian ilmu kimia merupakan ilmu yang sangat kompleks untuk dipelajari. Materi pelajaran kimia di sekolah menengah juga banyak berisikan konsep yang abstrak dan sulit dipahami. Hal tersebut mengakibatkan minat belajar siswa menjadi menurun yang akhirnya berdampak pada hasil belajar, sehingga hasil 
pembelajaran kimia berkualitas rendah

Kegiatan belajar mengajar merupakan suatu proses interaksi atau hubungan timbal balik antara guru dan siswa dalam suatu pembelajaran. Guru sebagai salah satu komponen dalam proses mengajar merupakan pemegang peranan yang sangat penting. Guru bukan hanya sebagai pemberi materi saja, melainkan juga sebagai pengatur jalannya proses pembelajaran di kelas. Oleh karena itu, guru harus mampu mengelola dan memperbaiki proses pembelajaran demi terciptanya kondisi belajar mengajar yang optimal.

Kegiatan pembelajaran pada mata pelajaran kimia kelas XII MIA 4 di SMA Negeri 2 Singaraja selama ini sudah berjalan dengan baik. Kelas XII MIA 4 SMA Negeri 2 Singaraja terdiri dari 36 siswa. Jumlah siswa yang banyak ini juga mempengaruhi suasana belajar di kelas. Disisi lain, terdapat berbagai permasalahan yang dijumpai dalam penyelenggaraan proses pembelajaran dikelas XII MIA 4 SMA Negeri 2 Singaraja. Beberapa permasalahan yang sering dijumpai guru dalam proses pembelajaran meliputi keaktifan siswa yang masih rendah, motivasi belajar siswa rendah, kemampuan bertanya dan memberikan jawaban yang masih kurang, serta kesiapan belajar siswa yang rendah. Permasalahan yang dirasa merupakan akar dari segala permasalahan yang ditimbulkan yakni kesiapan belajar siswa yang cukup rendah. Sejalan dengan observasi lapangan yang telah dilakukan, permasalahan mengenai kesiapan belajar siswa memang perlu ditangani dalam perbaikan proses pembelajaran di SMA Negeri 2 Singaraja.

Rendahnya kesiapan belajar siswa di kelas XII MIA 4 SMA Negeri 2 Singaraja tercermin dari kegiatan pembelajaran yang tidak berjalan optimal dikelas. Banyak siswa yang hanya sekedar datang kesekolah tanpa mempersiapkan segala materi untuk menunjang proses pembelajaran. Kesiapan belajar yang rendah akan mempengaruhi segala aktifitas belajar di kelas, mulai dari tidak bisa mengikuti materi yang diberikan hingga pada akhirnya siswa lebih memilih untuk mencontek dalam pengerjaan tugas-tugas ataupun pengerjaan tes tertulis.

Kesiapan belajar merupakan hal yang mendasar yang harus ada dalam diri seorang siswa untuk mengikuti pembelajaran di kelas. Siswa yang memiliki kesiapan belajar yang baik tentunya akan siap mengikuti pembelajaran di kelas dan akan memperoleh hasil belajar yang memuaskan. Slameto (dalam Rofatul Fuadz, 2012) menyatakan kesiapan adalah keseluruhan semua kondisi individu yang siap membuatnya siap untuk memberi respon atau jawaban didalam cara tertentu terhadap suatu situasi. Kesiapan belajar siswa sebelum mengikuti pembelajaran kimia di kelas sangat penting diperhatikan demi terciptanya suasana pembelajaran yang baik.

\section{Metode}

Penelitian ini merupakan penelitian tindakan kelas (classroom action research). Penelitian tindakan dalam bidang pendidikan yang dilaksanakan dalam kawasan kelas dengan tujuan untuk memperbaiki dan meningkatkan kualitas pembelajaran. Peningkatan kualitas yang dimaksud berkaitan dengan kesiapan belajar siswa yang ingin ditingkatkan melalui pemberian kuis sebelum proses pembelajaran berlangsung. Secara singkat PTK dapat didefinisikan sebagai suatu bentuk penelaahan penelitian yang bersifat reflektif dengan melakukan tindakan-tindakan tertentu agar dapat memperbaiki dan meningkatkan praktikpraktik pembelajaran di kelas secara lebih profesional. Penelitian ini dilakukan di SMA Negeri 2 Singaraja. Waktu penelitian tindakan kelas ini adalah dari tanggal 7 oktober hingga 28 oktober pada semester ganjil tahun 2016. Adapun subjek dalam peneltian ini adalah siswa kelas XII MIA 4 SMA Negeri 2 Singaraja semester ganjil tahun ajaran 2016/2017. Total siswa kelas XII MIA 4 sebanyak 36 orang, yang terdiri dari 21 siswa perempuan dan 15 siswa laki-laki.

Desain penelitian mengacu pada model Kemmis dan M.C Taggart, yang terdiri dari 4 komponen, yaitu: (1) perencanaan tindakan, (2) pelaksanaan tindakan, (3) observasi, dan (4) refleksi. Siklus pertama dilaksanakan dengan kompetensi dasar mengevaluasi gejala atau proses yang terjadi dalam contoh sel elektrokimia (sel volta dan sel elektrolisis) yang digunakan dalam kehidupan yaitu pada materi sel volta Sementara itu untuk siklus kedua dilaksanakan dengan kompetensi dasar sama dengan siklus pertama tetapi materi yag digunakan adalah elektrolisis dan ditambahkan dengan kompetensi dasar menganalisis faktorfaktor yang mempengaruhi terjadinya korosi dan mengajukan ide/gagasan untuk mengatasinya., dan menerapkan hukum/aturan dalam perhitungan terkait sel elektrokimia. Jenis data yang digunakan dalam penelitian ini adalah data kualitatif dan kuantitatif. Data kuantitatif pada penelitian ini yakni data tentang evaluasi hasil belajar siswa baik dari pemberian kuis maupun ulangan harian. Indikator peningkatan kesiapan belajar adalah adanya kecenderungan peningkatan persentase ketuntasan belajar siswa secara klasikal dari refleksi awal sampai siklus II, dan ini dijadikan dasar untuk mencapai hipotesis tindakan. Indikator keberhasilan 
penelitian tindakan kelas ini tercapai apabila meningkatnya kesiapan belajar siswa untuk mengikuti kegiatan pembelajaran dikelas ditandai dengan meningkatnya persentase ketuntasan belajar secara klasikal sebesar 20\% dari jumlah peserta didik.

\section{Hasil}

Secara umum, pelaksanaan pembelajaran di dalam kelas selama penelitian telah berlangsung sesuai dengan rencana pelaksanaan pembelajaran yang telah disusun. Penelitian ini dilaksanakan dalam dua siklus dengan subjek penelitian adalah siswa kelas XII
MIA 4 SMA Negeri 2 Singaraja sebanyak 36 orang siswa. Materi pelajaran yang dipelajari siswa di kemas dalam dua siklus pembelajaran, dimana masing-masing siklus dirinci menjadi empat kali pertemuan.

Data tentang kesiapan belajar siswa sebagai hasil pelaksanaan siklus I yang dikumpulkan melalui lembar observasi dan hasil tes akhir. Pada tahap pra siklus persentase ketuntasan belajar secara klasikal adalah $0 \%$. Data kesiapan belajar siswa jika dilihat dari hasil kuis setiap pertemuan dapat dilihat pada tabel berikut

Tabel 1. Data nilai rata-rata kuis siklus I

\begin{tabular}{cccc}
\hline Kuis & Pertemuan 1 & $\begin{array}{c}\text { Persentase } \\
\text { Pertemuan 2 }\end{array}$ & Pertemuan 3 \\
\hline Nilai rata-rata kelas & 35,83 & & 53,89 \\
\hline
\end{tabular}

Berdasarkan tabel tersebut dapat disimpulkan bahwa kesiapan belajar siswa kelas XII MIA 4 pada siklus I masih tergolong rendah dari pemberian kuis yang diberikan guru. Presentase ketutasan kuis pada siklus I sebesar 5,56 \% Walaupun hasil kuis siswa masih dibawah dari nilai ketuntasan minimal, tetapi secara umum terjadi peningkatan secara perlahan nilai rata-rata kuis siswa pada siklus I.

Berdasarkan hasil tes akhir siklus I dapat dilihat bahwa ketuntasan belajar siswa pada siklus I adalah $16,67 \%$ dengan rata-rata nilai sebesar 57,42. Hal ini menunjukan bahwa hasil belajar yang rendah berkaitan dengan kesiapan belajar siswa yang masih sangat rendah.

Dalam penerapan model pembelajaran 5M dengan pemberian kuis diawal pembelajaran yang diterapkan di kelas XII MIA 4 SMA Negeri 2 Singaraja untuk pokok bahasan Sel Volta, yaitu sebagai berikut. 1) Masih banyak siswa yang menganggap bahwa pemberian kuis hanya sekedar formalitas dan tidak mempengaruhi nilai mereka. 2) Selama kegiatan presentasi, siswa diberikan kesempatan untuk mempresentasikan hasil diskusi kelompoknya di depan kelas, namun ketika tampil di depan yang menyampaikan diskusi hanya siswa yang pintar di kelompokknya sedangkan anggota yang lain hanya mendampinginya. Hal ini disebabkan karena siswa yang lain belum terbiasa untuk mengungkapkan sesuatu di depan kelas. Siswa masih ada rasa malu dan takut untuk berbicara di depan kelas. 3) Selama kegiatan pembelajaran siklus I, sebagian besar siswa enggan untuk membaca buku ketika berdiskusi, sehingga ketika berdiskusi berkali-kali bertanya kepada guru. 4) Berdasarkan hasil obeserbasi pengerjaan tugas rumah yang dilakukan siswa, dimana rata-rata persentase siswa yang mengerakan tugas hanya 41,67\%. Persentase ini menunjukan kesiapan belajar siswa masih tergolong rendah. 5) Berdasarkan hasil tes akhir pada siklus I yang terdiri dari soal esay, terungkap bahwa siswa belum mampu mencapai KKM yang ditargetkan. Hal ini menunjukan bahwa kesiapan belajar siswa masih tergolong rendah.

Berdasarkan hasil refleksi pada siklus I maka peneliti melakukan beberapa perbaikan pada pembelajaran yang akan dilakukan pada siklus II. Adapun perbaikan yang direncanakan pada siklus II, yaitu sebagai berikut. 1) Peneliti memberikan kesempatan kepada siswa untuk memperbaiki bagian-bagian yang masih kurang sehingga bisa dilaksanakan lebih baik pada siklus II. Selain itu, LKS dibagikan sehari sebelum pembelajaran berlangsung. Hal ini bertujuan agar siswa bisa mempelajari rancangan di rumah sehingga pada saat pertemuan tatap muka siswa bisa langsung menanyakan hal-hal yang belum dipahami dari LKS tersebut dan juga agar siswa lebih siap dalam mengambil data saat praktikum maupun pengerjaan pemecahan masalah di LKS. 2) Memberikan kesempatan lebih banyak pada siswa untuk bertanya dan mengajukan pendapat mengenai materi yang dibahas selama proses pembelajaran berlangsung. Jika siswa yang ingin mengajukan pendapat masih itu-itu saja (monoton), maka peneliti menunjuk siswa yang kurang aktif dalam berpendapat untuk mencoba mengajukan pendapat sesuai pengetahuannya. Hal ini bertujuan agar siwa menjadai lebih berani dalam mengungkapkan pendapatnya tanpa takut lagi dicela oleh guru atau 
ditertawakan teman sekelasnya. 3) Memantau lebih intensif saat siswa melakukan praktikum dan diskusi kelompok agar semua anggota kelompok terlibat aktif didalamnya tanpa mengandalkan satu atau dua orang saja dari anggota kelompoknya. Hal ini bertujuan agar semua anggota kelompok mengetahui apa yang sedang dipelajari hari itu. Peneliti menekankan bahwa keberhasilan kelompok merupakan tanggung jawab semua anggota kelompok. Jadi anggota harus aktif dalam setiap aktivitas belajar. 4) Ketika presentasi agar semua kelompok terbiasa untuk menanggapi, maka peneliti juga akan mengungkapkan bahwa siswa yang aktif menanggapi maupun menambahkan hasil diskusi dari kelompok penyaji, maka akan mendapat nilai tambahan. Hal ini bertujuan agar siswa terbiasa untuk menanggapi atau menyampaikan pendapatnya ketika berdiskusi sehingga siswa tidak hanya menerima apa yang disampaikan oleh temannya. 5) Sebelum kegiatan diskusi dimulai, guru meminta siswa untuk membaca materi dan tanya jawab seputar materi tersebut, kelompok yang menjawab adalah kelompok yang ditunjuk oleh guru, jika tidak bisa menjawab berarti kelompok tersebut tidak memperoleh nilai. Bagi kelompok yang bisa menjawab, maka kelompok tersebut yang mendapatkan nilai. Sehingga terdapat motivasi untuk belajar. 6) Memberikan refleksi terhadap semua hasil portofolio siswa berupa hasil kuis, tugas-tugas, LKS, dan memberikan catatan langsung pada portofolio siswa yang akan dikembalikan. Hal ini bertujuan agar siswa mengetahui sejauh mana pemahamannya terhadap materi pelajaran dan termotivasi untuk lebih meningkatkan prestasinya yang berujung pada pemahaman konsep 7) Melakukan pendekatan secara individual kepada beberapa siswa yang hasil pemahaman konsepnya masih dibawah standar ketuntasan. Peneliti menanyakan kesulitas-kesulitan atau kendalakendala belajar yang dialami oleh siswa tersebut selama proses pembelajaran. Jika siswa menemui kesulitan lagi, maka siswa tersebut dapat dipersilahkan untuk bertanya baik saat di kelas maupun saat jam istirahat di sekolah.

Pada tahap evaluasi siklus II peniliti melakukan analisis terhadap hasil pengerjaan kuis siswa untuk mengetahui kesiapan belajar siswa pada siklus II. Berdasarkan hasil pengerjaan soal kuis diperoleh rata-rata nilai siswa sebesar 69,92. Nilai rata-rata tersebut menunjukkan bahwa kesiapan belajar siswa sudah tergolong baik. Hal tersebut ditunjukkan oleh rata-rata nilai siswa yang sudah berada di atas KKM. Rincian perolehan nilai siswa dalam mengerjakan soal kuis pada siklus II dapat dilihat pada Tabel 2 .

Tabel 2. Data nilai rata-rata kuis siklus II

\begin{tabular}{cccc}
\hline & \multicolumn{3}{c}{ Persentase } \\
\hline Kuis & Pertemuan 1 & Pertemuan 2 & Pertemuan 3 \\
Nilai rata-rata kelas & 60,11 & 73,06 & 76,03 \\
\hline
\end{tabular}

Berdasarkan tabel tersebut dapat disimpulkan bahwa kesiapan belajar siswa kelas XII MIA 4 pada siklus II dapat digolongkan baik dari segi pemberian kuis. Dapat dilihat terjadi peningkatan nilai rata-rata siswa dalam mengerjakan kuis yang diberikan. Presentasi ketuntasan siswa dalam mengerjakan kuis sebesar 63, 89\%. Apabila dibandingkan dengan nilai kuis siswa pada siklus I dapat dikatakan terjadinya peningkatan kesiapan belajar siswa sebesar 58,33\%. Perbandingan nilai kuis siklus I dan II dapat dilihat pada gambar berikut:

Nilai Kuis

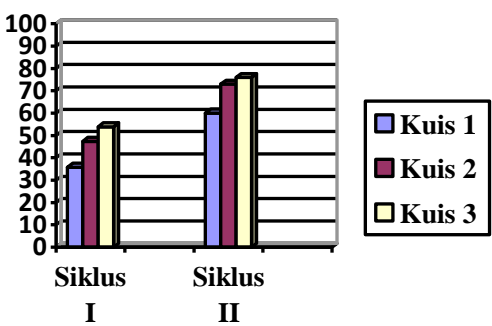

Gambar 1. Perbandingan nilai kuis pda siklus I dan II.
Berdasarkan hasil tes akhir siklus II dapat dilihat bahwa siswa yang tuntas sebanyak 27 orang dan yang tidak tuntas sebanyak 9 orang. Sehingga ketuntasan belajar siswa secara klasikal pada siklus II adalah $75 \%$ dengan rata-rata nilai 72,83. Hal ini menunjukan bahwa hasil belajar siswa cukup baik secara klasikal sehingga dapat dikatakan pada siklus II ini kesiapan belajar siswa sudah cukup baik dibandingkan dengan siklus I. Peningkatan hasil belajar secara klasikal dapat dilihat pada gambar 2 .

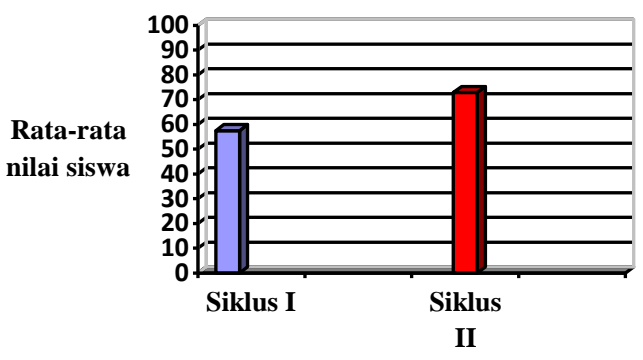

Gambar 2. Perbandingan nilai kuis pda siklus I dan II. 


\section{Pembahasan}

Berdasarkan penelitian yang telah dilaksanakan selama dua siklus di kelas XII MIA 4 SMA Negeri 2 Singaraja tahun pelajaran 2016/2017 pada semester ganjil, maka didapatkan hasil penelitian yang menunjukkan adanya peningkatan kesiapan belajar siswa melalui pemberian kuis di awal proses pembelajaran.

Berdasarkan hasil pengerjaan soal kuis pada siklus I, diketahui bahwa persentase ketuntasan siswa sebesar 5,56 \% dengan ratarata nilai sebesar 45,69. Berdasarkan data yang diperoleh diketahui dari 36 siswa yang hadir, rata-rata hanya 2 orang yang mendapatkan nilai di atas kriteria ketuntasan minimal yaitu diatas 68. Selain itu apabila dilihat dari hasil tes akhir siklus I, kesiapan belajar siswa masih sangat rendah. Persentase ketuntasan siswa secara klasikal 16,67\%, dimana hanya 6 siswa yang mampu mencapai KKM yang diharapkan yakni mendapatkan hasil tes diatas 68. Hasil tes yang belum mencapai KKM menunjukan bahwa kesiapan belajar siswa masih kurang. Masih rendahnya kesiapan belajar siswa pada siklus I disebabkan oleh beberapa kendala dan permasalahan yang telah diuraikan pada hasil refleksi pada siklus I.

Perbaikan yang dilakukan terhadap beberapa kendala dan permasalahan yang dihadapi telah dipaparkan pada perencanaan siklus II. Berdasarkan hasil pengerjaan soal kuis pada siklus II, diketahui bahwa persentase ketuntasan siswa sebesar $63,86 \%$ dengan ratarata nilai sebesar 69,73 . Berdasarkan data yang diperoleh diketahui dari 36 siswa yang hadir, rata-rata hanya 23 orang yang mendapatkan nilai di atas kriteria ketuntasan minimal. Peningkatan persentase ketuntasan dan nilai rata-rata, pada akhir siklus II juga dilaksanakan tes hasil belajar. Perolehan siswa dalam mengerjakan tes hasil belajar menunjukkan bahwa persentase ketuntasan sebesar 75\% dengan rata-rata nilai sebesar 72,83. Hal ini menunjukkan bahwa pemberian kuis di awal pembelajaran berpengeruh langsung terhadap peningkatkan hasil belajar siswa.

Berdasarkan hasil penelitian, diperoleh bahwa peningkatan persentase ketuntasan siswa dalam mengerjakan soal kuis dari siklus I ke siklus II yaitu sebesar 58,3 \% lebih besar daripada kriteria keberhasilan yang telah ditetapkan sebelumnya yaitu sebesar $20 \%$. Selain itu, dari pengerjaan tes hasil belajar diperoleh bahwa peningkatan persentase ketuntasan sebesar 58,33\%. Hasil tersebut menunjukkan bahwa penelitian tindakan kelas yang dilakukan sudah mampu mengatasi permasalah terkait rendahnya hasil kesiapan belajar dan hasil belajar siswa. Tercapainya kriteria keberhasilan sekaligus menandakan bahwa tindakan siklus II tidak dilanjutnya ke siklus III.

Baiknya kesiapan serta hasil belajar siswa kelas XI MIA 4 SMA Negeri 2 Singaraja tentunya tidak terlepas dari pemberian kuis di awal proses pembelajaran. Pemberian kuis di awal pembelajaran akan memotivasi siswa dalam meningkatkan kesiapan belajarnya. Selain itu, kuis yang diberikan secara kontinu dapat meningkatkan prestasi belajar sebab pada umumnya siswa akan berusaha aktif dan belajar lebih tekun untuk mendapatkan nilai yang baik. Hal ini sesuai dengan pendapat Ahmad (1990) yang menyatakan bahwa tes yang sering diadakan dapat meningkatkan prestasi belajar siswa sebab, tes akan mendorong dan mengharuskan mereka belajar lebih teratur, lebih rajin dan lebih tekun. Sadirman (1992) menyatakan bahwa para siswa akan lebih giat belajar kalau mengetahui akan ada kuis. Oleh karena itu memberikan kuis merupakan suatu sarana memotivasi belajar siswa.

\section{Penutup}

Berdasarkan hasil penelitian yang diperoleh dan pembahasan, maka dapat diambil simpulan bahwa pemberian kuis sebelum proses pembelajaran dapat meningkatkan kesiapan belajar siswa kelas XII MIA 4 SMA Negeri 2 Singaraja Tahun Ajaran 2016/2017. Berdasarkan hasil penelitian, diperoleh bahwa peningkatan persentase ketuntasan siswa dalam mengerjakan soal kuis dari siklus I ke siklus II yaitu sebesar 58,3 \%. Selain itu, berdasarkan hasil pengerjaan tes hasil belajar diperoleh peningkatan persentase ketuntasan siswa sebesar 58,33\%.

\section{Daftar Pustaka}

Dahar, Ratna Wilis. 1989. Teori-teori Belajar. Jakarta: Erlangga

De Porter, Bobby., Reardon, Mark., Singer-Nouri, Sarah. 2010. Quantum Teaching. Bandung: Kaifa.

Kirna, I M. 2010. Integrasi Hypermedia dalam Strategi Siklus Belajar Untuk Meningkatkan Pemahaman Konsep Kimia Siswa SMP yang Memiliki Dua Gaya Belajar Berbeda. Laporan Hibah Doktor. Malang: PPS UM

Mc. Taggart, R dan Kemmis, S. 1990. The Action Research Planner. Melbourne. Deakin University.

Mulyasa, H.E. 2011. Praktik Penelitian Tindakan Kelas. Bandung: PT Remaja Rosda Karya.

Purba, Michael. 2007. Kimia untuk SMA kelas XII 
IPA . Jakarta: Erlangga.

Sardiman, A.M. 2008. Interaksi dan motifasi Belajar mengajar. Raja Grafindo Persada. Jakarta

Slameto. (1998). Belajar dan faktor-faktor yang mempengaruhinya. Jakarta: PT Rineka Cipta.

Sardiman, A.M. (2011). Interaksi dan Motivasi Belajar Mengajar. Jakarta: Raja Grafindo Persada

Scott, Wendy A, dan Lisbeth H. Ytreberg. 1998.
Teaching English to Children. New York : Longman.

Undiksha. 2010. Buku Pedoman Studi Undiksha Tahun 2010. Singaraja: Undiksha.

Utami, Budi, Nugroho, Agung, dkk. 2009. Kimia untuk SMA/MA kelas XII IPA. Jakarta. Pusat Perbukuan, Departemen Pendidikan Nasional. 